\title{
Food supplies in the United Kingdom
}

\section{By A. H. J. BaInes, Statistics Division, Ministry of Agriculture, Fisheries and Food, London $S W_{I}$}

Since the Second World War the Ministry of Food (now the Ministry of Agriculture, Fisheries and Food) has annually assessed the United Kingdom's total supplies of food from all sources, that is, home production plus imports, with deductions for exports, wastage down to the point of measurement and non-food uses, and with adjustments for changes in measured stocks. The totals are divided by the 'mid-year' population to give average consumption per head. Imports are well recorded, and sources of information on home production include agricultural censuses and surveys and returns from processors. In order to reconcile the supplies with estimates obtained from consumers, some use is made of the evidence of the National Food Survey, which measures actual quantities of food entering private households in Great Britain. There are at present two 'yawning' gaps as regards catering usage and 'pipeline' stocks and until these are bridged a full reconciliation of sources is hardly possible.

Although both agricultural production and final consumption contribute largely to this exercise, experience has shown that the most convenient point of measurement is neither the first nor the last; it may be described as the first stage of processing, and the figures therefore represent disappearance into distribution rather than into final consumption. For example, wheat supplies could be measured as grain, as flour or as bread: the convention is to take the supply as the amount of flour produced. No account is normally taken of changes in 'end-year' wholesale, retail or household stocks; this amounts to an assumption that such stocks remain unchanged. In exceptional circumstances this assumption has to be abandoned. The movement of total sugar supplies, measured at a primary level, does not give an acceptable profile of consumption after 1973 when compared with evidence of usage, and it appears that after the panic in the summer of 1974 some of the additional supplies of refined beet sugar arriving towards the end of the year were not sold until i975. The additional amount entering and subsequently leaving the 'pipeline' is estimated at not less than $4 \mathrm{~kg} / \mathrm{head}$, and in this instance approximately $180 \mathrm{~kJ}(43 \mathrm{kcal}) /$ head per $\mathrm{d}(\mathrm{I} \cdot 5 \%$ of the energy value of total food supplies) had to be transferred from that year to the next.

The consumption levels enquiry began when this crowded island was under siege, not for the first time. For two centuries, since the Industrial Revolution began, Great Britain has been almost unique among major countries in importing a large proportion of its food, balancing its trade by exporting finished goods and providing services. Between the two World Wars our farmers and fishermen were producing approximately one-third of all the food eaten, and approximately half of 
the kinds of food grown in this country. The great leap forward after 1939 and the policies associated with the Agriculture Act, 1947 (ch. 48) raised the one-third to half, and the indigenous half to two-thirds. Sir Winston Churchill used to express his concern that a nation of fifty millions could feed only thirty millions from its own resources; even so he was over-stating our self-sufficiency. Even by 1973-74 the self-sufficiency ratio for the United Kingdom was only 0.55 by value for all foods and 0.68 for indigenous-type supplies (Ministry of Agriculture, Fisheries and Food, 1977). These proportions have since fallen, because of the adverse weather conditions of the past two seasons and the rise in the relative cost of food imports, itself largely due to similar difficulties elsewhere. Measured at constant (1970) prices, the self-sufficiency ratio did not fall until $1975-76$, though this gives us no more comfort than the somewhat similar observation that if the relative price of oil had not risen Britain would have had no 'balance of payments' problem. It is a stubborn fact that relative prices have shifted. Our spending on imported food and many other things has until this year been supported by international borrowing, and will henceforth be supported by the uncovenanted mercy of North Sea oil.

Our present discontents makes it hard to recall that in real terms personal disposable incomes were approximately $17 \%$ greater in 1975 than in 1970 , an increase more than double that recorded in the previous 5 years. That the rise was felt to be precarious is perhaps implied by the great increase in savings. In 1975 people were spending only $86 \%$ of the income left after deducting income tax and national insurance contributions.

No part of the rise in purchasing power after 1970 was devoted to household food purchases, though there is evidence that more meals were taken outside the home. The sectors in which real expenditure rose included durable goods, private motoring, housing, alcoholic drink and what may broadly be called recreation. The income elasticity of demand for food as a whole remains positive, though it has fallen below 0.2 when measured cross-sectionally at a point in time. In other words, a $1 \%$ difference in net income between households which are otherwise similar is associated with a difference of less than $0.2 \%$ in their household expenditure on food; this difference arises from quality as well as quantity. Yet as far as food supplies are concerned we have not even been on a plateau since 1970; rather on a gradual 'dip-slope'. Most of the fall in the quantities of food obtained is attributable to food prices having risen faster than other prices, a situation hitherto unfamiliar. This has caused shifts in purchasing patterns in favour of relatively cheaper foods; it has also led to less frequent but larger purchases, and has provided an incentive to waste less (the energy value of food supplies has not fallen below $12.2 \mathrm{MJ}(2910 \mathrm{kcal}) / \mathrm{head}$ per d, well above any tenable estimate of requirements, so that there is scope for reducing wastage both in distribution and in the home). These last two trends have been facilitated by a rapid growth in the ownership of deep-freezers, curiously parallel to the growth of refrigerators 16 years earlier. Most changes in habits begin in town and spread to the country; this one is spreading from the country house and the farm to the cities, and down the income scale, up the age scale, and from large families to small. 
All these pressures, however, have had little effect on the distribution of the average household food budget amongst broad categories of food. This apportionment changes over decades rather than years; in the short term, changes occur much more readily within the dozen or so broad categories than between them. It may thus be more appropriate to review the whole period since rationing ended in 1954 than to concentrate on the present decade.

The total consumption of milk and milk products other than butter, expressed in terms of milk solids, increased from $23.9 \mathrm{~kg} / \mathrm{head}$ in 1955 to $26.8 \mathrm{~kg} / \mathrm{head}$ in 1976 . Cheese and cream accounted for most of the rise, together with greater use of liquid milk in manufactured products. Consumption of liquid milk (obtained as such) has until this year remained fairly stable; the 'wartime' gains were consolidated, and the reduction in $197 \mathrm{r}$ in entitlements to free and reduced-price milk was partially compensated by increased purchases. Total meat consumption rose from $53.5 \mathrm{~kg} /$ head (edible weight) in 1955 to a peak of $6 \mathrm{r} \mathrm{kg} / \mathrm{head}$ in 1971 , but then fell to $55 \mathrm{~kg} /$ head in 1976 . Within this total, beef has maintained its lead despite its price. Consumption of mutton and lamb has fallen, at first slowly, then somewhat more rapidly; this looks like a change of generation, since purchases of lamb are associated with the housewife's age. Pork overtook lamb in I965 and Io years later was itself overtaken by poultry as runner-up to beef; however, the growth of deep-freezers may be expected to favour pig meat (pork rather than bacon). Regional differences are still in evidence for the meat group; the Scots maintain their historic relative preferences for beef (even beef sausages), the Londoners and Welsh for lamb and the Mercians (in the West Midlands of England) for pork. Nevertheless, in the short-run, housewives were prepared, or could be persuaded by the butcher, to shift their demand to whichever meat was currently plentiful; otherwise changes in relative prices would have been much greater than they were. (No judgment on this form of averaging is implied or intended.)

Fish consumption was at its height in the early post-war years; since $195^{8}$ there has been a decline especially in fresh, frozen and cured fish.

Total consumption of eggs and egg products reached 275 eggs/year in 1967 but was down to 249 /year in 1976 . The demand for eggs has become very inelastic over a wide price range, so that fairly small changes in supply lead to extreme fluctuations in price.

Total usage of visible oils and fats reached a peak in 1970 , not since exceeded. Butter consumption reached its post-war maximum in 1967 (still well below the 1934- 38 average) and margarine has fluctuated in relation to the supply of butter; but after making allowance for changes in real incomes and prices, the long-term trend in demand is still away from butter and towards margarine, probably because of the development of soft margarine.

Total usage of sugar has exhibited a downward drift since r96r.

Consumption of potatoes has declined during the period, at least up to 1972; then there were signs of a recovery through increased sales of potato products, but it remains uncertain whether the experience of the last 2 years, when poor crops 
forced consumption well down, will have a lasting effect. In normal years imports of 'ware' potatoes are prohibited but imported new potatoes have secured what is probably a permanent foothold in the first half of the year. For other fresh vegetables consumption has fluctuated according to the availability of supplies, but total usage of vegetables has increased as canning and quick-freezing have extended the seasons and given the housewife a wider choice. The prospects for fruit appear less favourable; in spite of relatively high income elasticities of demand, measured at a point in time, growth in real personal disposable income has led to no corresponding growth in purchases of fresh fruit, and lower levels of consumption from 1972 onwards have not been offset by any increase for canned fruit.

The most familiar example of a very long-term trend in consumption is the decline in grain products, especially bread. The motto of FAO is 'fiat panis', and since the agricultural revolution of the New Stone Age most consumers in most countries have obtained a large proportion of the energy value of their diet from cereals, which probably accounted for half the energy value of the British diet a century ago but less than one-quarter now. (It is no accident that the Ministry of Agriculture, Fisheries and Food's oldest statistical series, and until recently the only one it was legally obliged to maintain, is the Corn Returns, continuous since 177r.) Within a diminishing total there has been room for growth in demand for breakfast cereals, especially with what many would regard as the lamentable decline in the cooked breakfast, a distinctive contribution offered by Britain to civilization.

One may however hazard the generalization that any British habit which is not shared either by continental Europe or by the United States is at risk even in Britain. In addition to the English breakfast and the United Kingdom's relative preference for lamb, one might instance the weakening British predilection for tea rather than coffee (again, it is uncertain whether current shortages will have a lasting effect.)

The Ministry's definition of food includes tea, coffee and cocoa but not alcoholic beverages; the latter contributed approximately $420 \mathrm{~kJ}$ ( $100 \mathrm{kcal}) / \mathrm{head}$ per $\mathrm{d}$ in the 1950's, but their contribution has risen to $523 \mathrm{~kJ}$ (125 kcal)/head per $\mathrm{d}$ by 1969 and to $669 \mathrm{~kJ}(\mathrm{r} 60 \mathrm{kcal}) / \mathrm{head}$ per $\mathrm{d}$ in $\mathrm{I975}$. Since alcoholic drinks are not commonly consumed by children, this trend is relevant to assessments of dietary adequacy; the differences in this respect between households with and without children are understated if alcohol is ignored. The relative, though not of course the absolute, increases have been greater in wines and spirits than in beer.

These appear to be the main changes in food supplies since controls ended, but one naturally looks for broader generalizations. Lord Russell used to say that his concept of hell was a state where any generalization was no sooner established than it was falsified, so that no one could learn from experience. Certainly there have been occasions when consumer preferences have suddenly changed direction. After rationing ended, the growth of demand was initially directed to the staple foods which had been in short supply. Then in the 1960's growth in demand for 
food was concentrated on the convenience foods, and especially the quick-frozen foods. After 1970 growth shifted away from food altogether. Nevertheless, unless one is so unfortunate as to be at or near one of these infrequent turning-points, it is legitimate to assume that the near future can be predicted from the recent past, though trends in consumption must not simply be projected. One must first explain the trend in terms of known factors such as population, prices and incomes, develop one's multivariate model as far as the data warrant and statistical resources permit, and then put one's assumption about the future into the model. It is prudent to allow the model to include basic underlying trends which themselves remain unexplained. Not to do so would imply that if all known factors remain unchanged consumer behaviour will not change, which is clearly false. Even if nothing else changes, the past recedes; habits formed in youth persist but only until the stream of time carries them and us away. A curious example in our period is the Milk Marketing Board's finding (Empson, J. D.) that local differences in milk sales could not be explained simply in terms of present economic circumstances, but reflected those of the 1930's.

The annual consumption estimates are expressed in terms of energy value and nutrient content. As far as possible the series are comparable over time, but conversion factors have to be reviewed at intervals much shorter than those between editions of the invaluable McCance and Widdowson (Paul \& Southgate, 1977). Thus a substantial revision of the factors for meat in 1974 , based on new analytical evidence, accounts for a fall of $293 \mathrm{~kJ}(70 \mathrm{kcal}) / \mathrm{head}$ per $\mathrm{d}$, and is responsible for most of the apparent decrease in fat and iron in that year. Even the definition of the edible portion of a commodity is not unchangeable. There was a time when sheep's heads were acceptable to housewives, but not now.

Comparison between more and less favoured groups at a point in time, as well as trends over a period of time, confirms that the British consumer's collective inclination is towards a diet which is relatively high in fat but low in carbohydrate, and in which protein and fat both come from animal rather than vegetable sources. Further, even when the energy content of the diet has declined, the supply of many nutrients has been well maintained, and in that sense the quality of the diet has tended to improve. A statistician, however, does well to make his statements descriptive rather than prescriptive. Which goods are superior and which inferior depends in our terminology solely on consumer preference, irrespective of their nutritional value. Nutritional considerations play no direct part in econometrics, unless and until they affect consumer choice.

\section{REFERENCES}

Empson, J. D. (1958). J. Dairy Res. 25.

Ministry of Agriculture, Fisheries and Food (1977). Food Facts no. 5.

Paul, A. A. \& Southgate, D. A. T. (I977). McCance and Widdowson's The Composition of Foods. London: HM Stationery Office (In the Press). 